\title{
Electrochemical Method of Obtaining of Electric Current from Thermal Energy Using Graphite Electrodes
}

\author{
S.S. Yegeubayeva ${ }^{a, *}$, A.B. BAyeshov ${ }^{b}$, A.K. Bayeshova ${ }^{b}$ \\ ${ }^{a}$ Kazakh-British Technical University, Almaty, 050000, Kazakhstan \\ ${ }^{b}$ D.V. Sokolskii Institute of Organic Catalysis and Electrochemistry, Almaty, 050000, Kazakhstan

\begin{abstract}
Here we present the possibility of using the electrochemical processes to convert solar thermal energy or geothermal energy into electricity, based on fundamental and experimental research. Laboratory setup for converting thermal energy into electrical energy is the glass electrolyzer consisting of two electrode spaces connected with electrolytic bridge. The influence of the temperature difference between the electrode formation spaces on the EMF and the short circuit current (SCC) between graphite electrodes in aqueous solutions was studied. In solution of $100 \mathrm{~g} / \mathrm{l}$ of sodium hydroxide the values of the EMF, SCC and oxidation-reduction potential are $80.0 \mathrm{mV}, 44.1 \mu \mathrm{A}$ and $95 \mathrm{mV}$, respectively. These values are substantially higher than those of the acidic and neutral solutions. This is due to the fact that in the alkaline solution the oxidation of hydroquinone, 1,4-benzoquinone is reversible and provides good reproducible electrode potential, which depends on the $\mathrm{pH}$. The coefficient of conversion of thermal energy into electrical energy is $1.14 \mathrm{mV} / \mathrm{deg}$.
\end{abstract}

DOI: 10.12693/APhysPolA.128.B-455

PACS: 88.05.Ec, 88.10.--g

\section{Introduction}

It is difficult to imagine the world's economical and technological development without the use of the renewable energy sources. The principal sources of alternative energy include the energy of the Sun, biomass, wind and the energy of the geothermal waters. There are examples of use of the geothermal energy of the Earth for electric power generation and for heating and cooling of buildings. Technologies using the renewable energy sources are ecologically clean and do not harm the environment [1-5].

Internationally the provision of electrical power is currently dominated by fossil fuels: coal, oil and gas. The carbon emissions of fossil fuels, in view of climate change, exert pressure on nations to generate a greater proportion of electricity by alternative technologies. In addition, the increasing volatility of the costs of oil and gas means that fossil fuels become less attractive as the major energy sources for a country. The non-fossil based alternative electricity generation technologies are the nuclear power or the renewable energy.

The advantages of renewable energy technologies, are the reduced carbon emissions and the reduced usage of fossil fuels. In a nation's electrical supply industry the decision to adopt a particular renewable technology will be influenced by geographic factors, by economic factors (capital and operating costs, nature of the resulting revenue streams, access to finance) and by its current portfolio of energy provision $[6-8]$.

In this report we present the possibility of using electrochemical processes to convert solar thermal energy or

*corresponding author; e-mail: salamat.egeubaeva@mail.ru geothermal energy into electricity. It was developed using fundamentally new electrochemical method for converting thermal energy into electrical energy [9].

\section{Experimental section}

Experimentally we have established, that at immersing of two electrodes into a water solution of the electrolytes containing the ions in oxidized and reduced forms and at creation of a difference of temperatures in the interelectrode space, an electromotive force (EMF) appears in the system and on the electrodes the oxidation-reduction potential, which value is defined by Nernst equation, is established [10]:

$$
E=E^{0}+\frac{R T}{n F} \ln \frac{a_{\mathrm{ox}}}{a_{\text {red }}} .
$$

The laboratory installation for transformation of thermal energy to the electrical consists of two glass electrolyzers which are connected through the bottom part by the electrolytic bridge in the form of a tubule (Fig. 1). Electrolyzers are filled with solutions of electrolytes. The first electrolyzer (1) has thermostated shirt, attached to a thermostat. It is possible to fix the temperature of first electrolyzer to any value within $20-90{ }^{\circ} \mathrm{C}$ range. The first thermostated electrolyzer (1) in which the working graphite electrode (4) is located, is connected through the glass bridge (10) with the vessel (9) filled with the saturated solution of potassium chloride. The reference silver-chloride cell which measures the values of the potential established on the graphite electrode (4) is placed in vessel (9). The glass bridge (10) is filled with the investigated solution.

The influence of the temperature difference between the electrodes formation space on the EMF and the short circuit current (SCC) between graphite electrodes in an aqueous solution was investigated. 


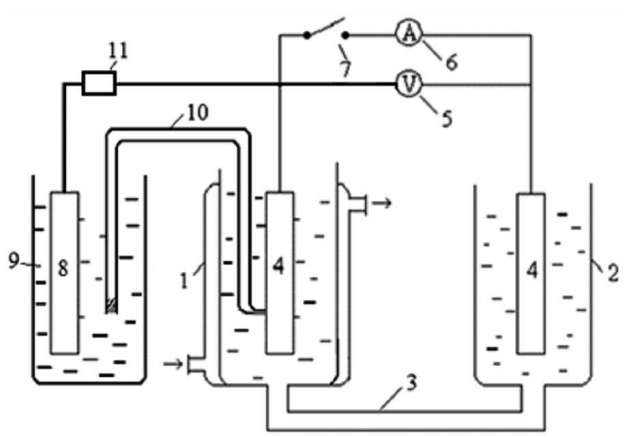

Fig. 1. The scheme of setup for research of transformation of thermal energy to electrical: 1 - thermostated electrolyzer; 2 - non-thermostated electrolyzer; 3 the bridge connecting the electrode spaces, 4 - graphite electrodes; 5 - the voltmeter for measurement of the EMF value; 6 - the ampermeter for measurement of SCC value; 7 - switch; 8 - reference electrode; 9 vessel with the saturated solution of potassium chloride; 10 - glass bridge filled with the investigated solution; 11 - potentiometer.

When the graphite electrodes are immersed into the solution of sodium hydroxide with a concentration of $100 \mathrm{~g} / \mathrm{l}$ and containing quinine and hydroquinone at concentration higher than $3 \mathrm{~g} / \mathrm{l}$, process on the surface of electrodes reaches following equilibrium.

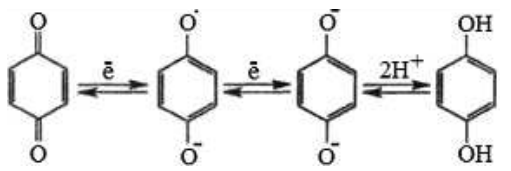

The value of potential depends on temperature and is given by the Nernst equation with $E^{0}=0.69 \mathrm{~V}$.

\section{Results and discussion}

The ability to participate in quinone reduction reactions was characterized by reduction potential. The quinine reduction ability is usually increased by electron acceptors and decreased by donors [11-13]. Under the influence of mild reduction, the quinines are easily converted into hydroquinone and simplest restored benzoquinones [14]. At increasing the temperature difference in the electrode spaces of the electrolyzer to $70^{\circ}$, the EMF between the electrodes and short-circuit current are equal to zero (Table I). The oxidation-reduction

TABLE I

Changes in EMF values, SCC and oxidation-reduction potential as functions of temperature difference in the electrode spaces.

\begin{tabular}{c|c|c|c|c|c|c|c|c}
\hline \hline$\Delta t,\left[{ }^{\circ} \mathrm{C}\right]$ & 0 & 10 & 20 & 30 & 40 & 50 & 60 & 70 \\
\hline$E,[\mathrm{mV}]$ & 0 & 0 & 0 & 0 & 0 & 0 & 0 & 0 \\
\hline$I,[\mathrm{~mA}]$ & 0 & 0 & 0 & 0 & 0 & 0 & 0 & 0 \\
\hline$\Delta E,[\mathrm{mV}]$ & 0 & 13.6 & 21.8 & 30.9 & 41.3 & 47.5 & 54.3 & 58.1 \\
\hline
\end{tabular}

Note: $\mathrm{c}\left(\mathrm{C}_{6} \mathrm{H}_{4} \mathrm{O}_{2}\right)=3 \mathrm{~g} / \mathrm{l}, \mathrm{c}\left(\mathrm{C}_{6} \mathrm{H}_{4}(\mathrm{OH})_{2}\right)=3 \mathrm{~g} / \mathrm{l}, t_{0}=20^{\circ} \mathrm{C}$ potential of graphite electrode increases with temperature and at $70^{\circ} \mathrm{C}$, the difference increases to $58.1 \mathrm{mV}$.

As we see from Table II and III, when the temperature is the same in the left and the right spaces of electrolyzer, the EMF between graphite electrodes does not forme. In the sulfuric acid solution with a concentration of $100 \mathrm{~g} / \mathrm{l}$ and in solution mixture comprising $50 \mathrm{~g} / \mathrm{l}$ of sulfuric acid and $50 \mathrm{~g} / 1$ of sodium sulfate, in the presence of oxidation-reduction systems of quinone and hydroquinone $(3 \mathrm{~g} / \mathrm{l})$, at temperature difference of $70^{\circ} \mathrm{C}$, the value of EMF and SCC, reache respectively, $28.0 \mathrm{mV}$ and $13.5 \mu \mathrm{A}$, which is relaed with the increase of conductivity of the solution.

TABLE II

Changes in EMF, SCC and oxidation-reduction potential values, with the increase of the temperature difference in the electrode spaces in sulfuric acid solutions.

\begin{tabular}{c|c|c|c|c|c|c|c|c}
\hline \hline$\Delta t,\left[{ }^{\circ} \mathrm{C}\right]$ & 0 & 10 & 20 & 30 & 40 & 50 & 60 & 70 \\
\hline$E,[\mathrm{mV}]$ & 0 & 15 & 38 & 72 & 95 & 125 & 181 & 28.0 \\
\hline$I,[\mu \mathrm{A}]$ & 0 & 1.0 & 21 & 3.0 & 42 & 62 & 85 & 135 \\
\hline$\Delta E,[\mathrm{mV}]$ & 0 & 51 & 86 & 125 & 158 & 193 & 256 & 351 \\
\hline
\end{tabular}

TABLE III

Changes in EMF, SCC and oxidation-reduction potential values, with the increase of the temperature difference in the electrode spaces in electrolyte containing sulfuric acid and sodium sulfate.

\begin{tabular}{c|c|c|c|c|c|c|c|c}
\hline \hline$\Delta t,\left[{ }^{\circ} \mathrm{C}\right]$ & 0 & 10 & 20 & 30 & 40 & 50 & 60 & 70 \\
\hline$E,[\mathrm{mV}]$ & 0 & 3.0 & 55 & 82 & 121 & 155 & 213 & 281 \\
\hline$I,[\mu \mathrm{A}]$ & 0 & 13 & 22 & 38 & 55 & 75 & 102 & 141 \\
\hline$\Delta E,[\mathrm{mV}]$ & 0 & 5.0 & 103 & 153 & 215 & 254 & 335 & 373 \\
\hline
\end{tabular}

TABLE IV

Changes of EMF, SCC and oxidation-reduction potential, as function of temperature difference in the electrode spaces in sodium sulphate solution.

\begin{tabular}{c|c|c|c|c|c|c|c|c}
\hline \hline$\Delta t\left[{ }^{\circ} \mathrm{C}\right]$ & 0 & 10 & 20 & 30 & 40 & 50 & 60 & 70 \\
\hline$E,[\mathrm{mV}]$ & 0 & 35 & 95 & 21.0 & 30.0 & 38.0 & 473 & 56.0 \\
\hline$I, \mu \mathrm{A}$ & 0 & 21 & 62 & 132 & 191 & 251 & 29.3 & 31.0 \\
\hline$\Delta E,[\mathrm{mV}]$ & 0 & 132 & 259 & 377 & 523 & 655 & 778 & 888 \\
\hline
\end{tabular}

During the experiment, in the solution of sodium sulphate $(100 \mathrm{~g} / \mathrm{l})$ and a solution containing $50 \mathrm{~g} / \mathrm{l}$ sodium sulphate and $50 \mathrm{~g} / \mathrm{l}$ of sodium chloride in the presence of red-ox system $\mathrm{C}_{6} \mathrm{H}_{4} \mathrm{O}_{2}-\mathrm{C}_{6} \mathrm{H}_{4}(\mathrm{OH})_{2}$ of $3 \mathrm{~g} / \mathrm{l}$, the amount of EMF generated between the electrodes and the SCC are significantly increased and constitute $56.0 \mathrm{mV}$ and 
$31.0 \mu \mathrm{A}$ respectively. These results are presented in Tables IV and V. The maximum change of oxidationreduction potential was $88.8 \mathrm{mV}$.

TABLE V

Changes of EMF, SCC and oxidation-reduction potential, as function of the temperature difference in neutral solution.

\begin{tabular}{c|c|c|c|c|c|c|c|c}
\hline \hline$\Delta t,\left[{ }^{\circ} \mathrm{C}\right]$ & 0 & 10 & 20 & 30 & 40 & 50 & 60 & 70 \\
\hline$E,[\mathrm{mV}]$ & 0 & 71 & 18.0 & 263 & 351 & 43.0 & 492 & 541 \\
\hline$I,[\mu \mathrm{A}]$ & 0 & 25 & 8.0 & 141 & 192 & 243 & 282 & 312 \\
\hline$\Delta \mathrm{E},[\mathrm{mV}]$ & 0 & 9.0 & 174 & 287 & 412 & 555 & 687 & 79.0 \\
\hline
\end{tabular}

TABLE VI

Changies of EMF, SCC and oxidation-reduction potential values, as functions of the temperature difference in the electrode spaces in alkaline solution.

\begin{tabular}{c|c|c|c|c|c|c|c|c}
\hline \hline$\Delta t,\left[{ }^{\circ} \mathrm{C}\right]$ & 0 & 10 & 20 & 30 & 40 & 50 & 60 & 70 \\
\hline$E,[\mathrm{mV}]$ & 0 & 2. & 7.1 & 15.0 & 26.2 & 421 & 60.0 & 80.0 \\
\hline$I,[\mu \mathrm{A}]$ & 0 & 1.3 & 35 & 9.3 & 16.0 & 23.1 & 323 & 44.1 \\
\hline$\Delta E,[\mathrm{mV}]$ & 0 & 9 & 20 & 39 & 52 & 69 & 80 & 95 \\
\hline
\end{tabular}

Note: $\mathrm{c}\left(\mathrm{C}_{6} \mathrm{H}_{4} \mathrm{O}_{2}\right)=3 \mathrm{~g} / \mathrm{l}, \mathrm{c}\left(\mathrm{C}_{6} \mathrm{H}_{4}(\mathrm{OH})_{2}\right)=3 \mathrm{~g} / \mathrm{l}$,

$\mathrm{c}(\mathrm{NaOH})=100 \mathrm{~g} / \mathrm{l}, t_{0}=20^{\circ} \mathrm{C}$

As can be seen from Table VI, in solution of $100 \mathrm{~g} / \mathrm{l}$ sodium hydroxide, the values of the EMF, SCC and oxidation-reduction potential constitute $80.0 \mathrm{mV}$, $44.1 \mu \mathrm{A}$ and $95 \mathrm{mV}$, respectively. These are substantially higher than the values in the acidic and neutral solutions. This is due to the fact that the in alkaline solution the oxidation of hydroquinone, 1,4-benzoquinone is reversible and provides good reproducible electrode potential, which depends on the $\mathrm{pH}$.

At a constant temperature difference between the electrode spaces of the cell, the values of EMF, and SCC are stabilized within intervals of $33.0-25.0 \mathrm{mV}$ and $0.021-$ $0.018 \mathrm{~mA}$, respectively, and the redox potential of the electrode during $90 \mathrm{~min}$ changes to $19.9 \mathrm{mV}$ as shown in Fig. 2.

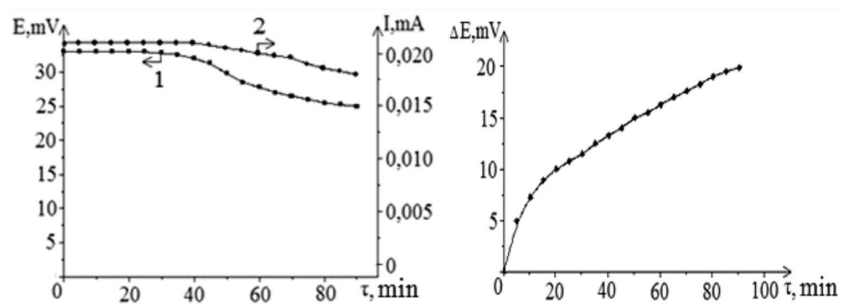

Fig. 2. Time dependence of EMF (1), SCC (2) and redox potential between the graphite electrodes during of the experiment.

\section{Conclusions}

Thus, while implementing the electrochemical method of converting thermal energy into electrical energy using graphite electrode in aqueous solutions in the presence of a red-ox system of "quinone-hydroquinone", the maximum value of the electromotive force of $80.0 \mathrm{mV}$ is generated in sodium hydroxide solution, however the value of $\mathrm{SCC}$ is $44.1 \mu \mathrm{A}$. The coefficient of conversion of thermal energy into electrical energy is $1.14 \mathrm{mV} / \mathrm{deg}$.

\section{References}

[1] S.S. Yegeubayeva, A.B. Bayeshov, A.K. Bayeshova, M.Zh. Zhurmov, Int. J. Chem. Sci. 12, 456 (2014).

[2] N.A. Nazarbayev, Global Energy Strategy for Sustainable Development in XXI century, Economy, Moscow 2011.

[3] P.P. Bezrukih, YU.D. Arbuzov, G.A. Borisov, V.I. Vissarionov, V.M. Evdokimov, N.K. Malinin, N.V. Ogorodov, V.N. Puzakov, G.I. Sidorenko, A.A. Shpak, The resources and the efficient use of renewable energy sources in Russia, Nauka, St. Petersburg 2002.

[4] A. Luke, Power Saver. 4, 57 (2007).

[5] G. Doroshin, Review of Environment and Sustainable Development in Kazakhstan, Almaty 2004.

[6] M. Nigel, I. Towhidul, Modelling European usage of renewable energy technologies for electricity generation, Technological Forecasting \& Social Change, TFS-17979, (2014) p. 13.

[7] G. Erdmann, IJMP 3, 143 (2001).

[8] A. Satkaliev, Kazakhstan Today 8, 2 (2011).

[9] A. Baeshov, S.A. Baeshova, A.K. Baeshova, Thermal energy transformer to the electric, Patent No. 24466 (2011) p. 8.

[10] A.L Rothinyan, K.I Tikhonov, I.A Shoshina, Theorethical electrochemistry, Chemistry, Leningrad 1981.

[11] D. Kaesong, Organic Reactions, Foreign literature, Moscow 4, 270 (1951).

[12] P. Karrer, Course of Organic Chemistry, 2nd ed., Leningrad 1962.

[13] L. Fieser, M. Fieser, Organic Chemistry, Advanced Course, Chemistry, Moscow 1996.

[14] L.S. Efros, M.V. Gorelik, Chemistry and Technology of intermediates, Chemistry, Leningrad 1980. 